\title{
W nurcie tak zwanej nowej ewangelizacji. Próba rekonstrukcji językowego obrazu ewangelizacji w Biblii, Katechizmie Kościoła Katolickiego i tekstach współczesnych ewangelizatorów
}

W nauczaniu Soboru Watykańskiego II (por. m.in. opracowania Wiltgen 2001; de Mattei 2012; Białkowski (red.) 2014) kluczowym terminem jest apostolstwo, z którym teolodzy posoborowi łączą termin ewangelizacja. Ojciec św. Jan Paweł II wskazywał ponadto jeden z jej aspektów, używając wyrażenia nowa ewangelizacja. Wezwanie do nowej ewangelizacji wiązało się u niego z troską o współczesną misję Kościoła, z uwzględnieniem zmian cywilizacyjnych i kulturowych.

Analizie leksykalno-semantycznej poddano pojęcie ewangelizacji. Celem analizy jest odpowiedź na pytanie, jaka jest jego struktura kognitywna w Biblii, w Katechizmie Kościoła Katolickiego (KKK) oraz w wybranych tekstach źródłowych związanych z nurtem tzw. nowej ewangelizacji. Materiałem są: publikacje z kręgu katolickiej Odnowy w Duchu Świętym z lat 90. XX wieku (Forrest 1997; Kozłowski 1997 i kolejne wydanie - 2015) oraz z kręgu protestanckiego nauczania, mającego wpływ na grupy charyzmatyczne różnych denominacji od połowy lat 90. XX wieku (Wimber, Springer 1991), a także przekaz współczesnych katolickich ewangelizatorów (Cadeddu, Porcu 2015).

Oparto się przy tym na definicji językowego obrazu świata sformułowanej przez Jerzego Bartmińskiego (2009). Próbę rekonstrukcji językowego obrazu ewangelizacji podjęto na podstawie metody etnolingwistyki. Posłużono się opisem zintegrowanym, który odpowiada wymogom tej dziedziny rozumianej jako lingwistyka antropologiczna. Wiąże się zatem z ujmowaniem języka w kontekście kultury.

W celu ujawnienia najważniejszych składników struktury kognitywnej badanego leksemu J. Bartmiński proponuje analizować wypowiedzi z nim ,pod ką- 
tem tego, na jakie niejawne pytania odpowiadają (do jakich aspektów pojęcia się odnoszą)" (Różyło: 224). Daje to bowiem możliwość stwierdzenia, jakie cechy nazywanego danym słowem pojęcia są istotne dla autorów tekstów. Tym samym wskazuje się cechy najsilniej utrwalone, narzucające strukturę kognitywną badanemu pojęciu.

Propozycja kategoryzacji jest oparta na tradycji istniejącej w logice i językoznawstwie, zwłaszcza w słowotwórstwie, składni i semantyce (Fillmore 1968; Apresjan 1980; Wierzbicka 1985; Tokarski 1988; Nikitina 1992), a sięgającej Arystotelesa (por. Bartmiński 1996: 9-34).

Definicje ewangelizacji w analizowanych tekstach stanowią zatem specyficzne profile tego pojęcia. Są one efektem

subiektywnej (tj. mającej swój podmiot) operacji językowo-pojęciowej, polegającej na swoistym kształtowaniu obrazu przedmiotu poprzez ujęcie go w określonych aspektach (podkategoriach, fasetach), takich jak np. pochodzenie, cechy, wygląd, funkcje, zdarzenia, przeżycia itp., w ramach pewnego typu wiedzy i zgodnie z wymogami określonego punktu widzenia (Bartmiński, Niebrzegowska 1998: 212).

Dla ewangelizacji są nimi: przedmiot ewangelizacji (co?), podmiot ewangelizacji (kto? kogo?), miejsce (gdzie?), czas (kiedy?), sposoby i metody ewangelizacji (jak?), okoliczności zaistnienia (uwarunkowania) ewangelizacji (jakie?), działania sprawcze ewangelizacji (jaki cel? skutek?), definicje ewangelizacji, działania wobec ewangelizacji (co się z ewangelizacją robi?), działania ewangelizacji (co robi ewangelizacja?), cechy ewangelizacji (jaka?), zjawiska związane z ewangelizacją (coś ewangelizacji?), to, co służy do ewangelizacji (coś do ewangelizacji?).

Frazy zawierające leksem ewangelizacja zaczerpnięte z Biblii, KKK i innych tekstów źródłowych przedstawiono zatem w układzie fasetowym. Przy ich wyborze nawiązano do koncepcji zdania minimalnego, tj. zdania samodzielnego pod względem semantycznym i zawierającego tylko pozycje obligatoryjne, konieczne (por. Karolak 1984: 11-210).

Punktem wyjścia prowadzonych badań jest przywołanie znaczenia kodowego leksemu ewangelizacja w słownikach języka polskiego.

Źródła leksykograficzne ujmujące stan polszczyzny doby staro- i średniopolskiej notują tylko wyraz ewangelia, którą Stownik staropolskiej terminologii chrześcijańskiej (s. 37) definiuje jako: 1. 'jedną z ksiąg opisujących życie i naukę Chrystusa, wyjątek z takiej księgi' a. 'jedną z ewangelii apokryficznych', b. 'kazanie, wykład tekstu Ewangelii, homilię’; 2. 'naukę chrześcijańską'; analogicznie Stownik staropolski (II: 348). W Słowniku polszczyzny XVI wieku występują hasła Ewanjelija (VI: 567-575) w znaczeniach: 1. 'dobra nowina, wiadomość; nauka Nowego Testamentu głoszona przez Chrystusa, apostołów i kościół katolicki’, przen. a. 'chrześcijaństwo', b. 'islam' czy 'nauka chrześcijańska głoszona przez różnego rodzaju niekatolickie wyznania chrześcijańskie’; 2. 'działalność i nauka Chrystu- 
sa spisana przez apostołów w czterech pierwszych księgach Nowego Testamentu lub w księgach zwanych ewangeliami apokryficznymi; 3. 'książka zawierająca cały tekst lub fragmenty Ewangelii albo cały Nowy Testament'; 4. 'część Mszy św.'; 5. 'czynność głoszenia ewangelii'oraz Ewanjelijon (VI: 575-576) w znaczeniach 1, 2 i 5, a także Ewanjelijum (VI: 576-577) - por. znaczenia 1, 2, 3.

Prawdopodobnie wraz z nurtem reformacyjnym pojawiła się potrzeba utworzenia wyrazu nominującego 'czynność głoszenia Ewangelii'. Słowniki doby nowopolskiej (np. słownik Lindego I: 632-633; słownik wileński I: 302-303; słownik warszawski: 706; słownik Doroszewskiego II: 772-773) notują już zatem zarówno ewangelię, jak i neologizm słowotwórczy ewangelizować. Jednak, poczynając od słownika warszawskiego (s. 706), oprócz haseł ewangelia i ewangelizować pojawia się odrębny wyraz hasłowy ewangelizacja ze wskazaniem na znaczenie takie, jak 'opowiadać Ewangelię, szerzyć naukę Jezusa Chrystusa'. W słowniku Doroszewskiego występuje z kwalifikatorem kult. w znaczeniu 'głoszenie ewangelii, nawracanie za pomocą głoszenia ewangelii'. Wydania internetowe Słownika języka polskiego zapisują definicje 'propagowanie głównych kanonów wiary chrześcijańskiej, a przede wszystkim nauki o Jezusie' lub z kwalifikatorem teol. 'głoszenie ewangelii (jakość wiary)' i 'chrystianizowanie, zabieganie o wzrost liczby członków Kościoła (ilość wierzących)’ (http://sjp.pl/ewangelizacja). Tak więc Ewangelia to dziś przede wszystkim 'dzieło pisane, przedstawiające życie Jezusa' albo 'fragment tego dzieła, czytany podczas każdej Mszy świętej'. Natomiast ewangelizacja to 'głoszenie Ewangelii' i 'działalność misyjna'.

Typowe kolokacje ze słowem ewangelizacja wynotowane ze współczesnych słowników języka polskiego wskazują, że do określenia znaczenia ewangelizacji istotne są następujące jej aspekty: działania sprawcze ewangelizacji (np. powstanie pod wpływem ewangelizacji licznych chrześcijańskich kościołów), miejsce ewangelizacji (np. Azja Mniejsza), cechy ewangelizacji (np. nowa, uliczna, Ameryki) i to, co służy ewangelizacji (np. diakonia do spraw ewangelizacji, sekretariat do spraw ewangelizacji) (https://pl.wiktionary.org/wiki/ewangelizacja).

Dla późniejszych rozważań ważny jest także biblijny obraz ewangelizacji (por. Kulwicka-Kamińska 2008; 2008-2009).

W Starym Testamencie (ST) obecny jest wyraz ewangelia w znaczeniu 'dobra, radosna wiadomość'. Język hebrajski na oznaczenie ogłaszania dobrych nowin z dziedziny życia prywatnego lub narodowego dysponował wyrazami bêsôrāh 'dobra/radosna wiadomość', stąd czasownik bāŝar 'ucieszyć kogoś dobrą wiadomością, zwiastować' oraz bềrāh 'dobra/radosna wiadomość'; 'nagroda za dobrą wiadomość' (Briks (red.) 2000: 66-67). W przekładach ST na język polski hebrajski źródłosłów be ŝôāh ma ekwiwalenty zarówno jedno-, jak i wielowyrazowe, np. $2 \mathrm{Sm} \mathrm{4,} 10$ poselstwo (translacje staropolskie), wieść radosna $\left(\mathrm{BT}^{1}\right) ; 2 \mathrm{Krl}$ 7, 9 dobre poselstwo (BB), dobra nowina (BW, BG), radosna nowina $(\mathrm{BT})$ itp. Wartość czysto religijną przybiera słowo ewangelia dopiero u Iz 40-66. Oznacza wówczas

\footnotetext{
${ }^{1}$ Rozwinięcie skrótów tekstów źródłowych znajduje się na końcu artykułu.
} 
'zapowiedź przyjścia Zbawiciela'. W przekładach ST nie pociąga to za sobą zasadniczych zmian w zakresie użycia polskich ekwiwalentów semantycznych por. nowiny (BB), dobra nowina (BN), rzeczy pocieszne (BG), dobre nowiny (BT) w Iz 40, 9, jednakże oprócz nich wprowadza się też odpowiednik ewangelia. Jest on częściej obecny na kartach BW (np. Iz 40, 9; Ps 68, 12) niż w staropolskich translacjach innowierczych (tu np. w BB i BG Iz 61, 1). Nie występuje w BT.

Nowy Testament (NT) nawiązuje do prorockiego przekazu Deutero-Izajasza. Tu ewangelia oznacza 'dobrą nowinę o zbawieniu' - z gr. euangelion 'dobra wiadomość, dobra (szczęśliwa) nowina; ewangelia'; w NT tylko o szczęśliwej nowinie, pochodzącej od Boga i przekazywanej ludziom poprzez powołanych przez Niego wysłańców' (Popowski (red.) 1994: 239). W polskich przekładach NT, oprócz znanych już ze ST wyrażeń typu wdzięczne poselstwo, dobra nowina, wesoła nowina, radosna wieść, dobra wiadomość itp., tłumacze wykorzystują w przeważającej liczbie kontekstów wyraz ewangelia jako ekwiwalent gr. euangelion (np. Łk 4, 18).

Przekładom biblijnym nie jest natomiast znany termin ewangelizacja. Wyjątek stanowi Biblia Poznańska, w której w Flp 4, 15 czytamy: Sami przecież wiecie, moi Filipianie, że w poczatkach ewangelizacji, gdy wyszedtem z Macedonii, poza wami żaden [inny] Kościót nie brat udziału w moim rozrachunku: daję — biorę. W BT zastosowano translat opisowy gloszenie Ewangelii.

Konteksty biblijne potwierdzają, iż Ewangelia to nie tylko nazwa świętej księgi, lecz żywe słowo Boga skierowane do człowieka. Wykładnikami formalnymi tego znaczenia są towarzyszące leksemowi ewangelia czasowniki związane z sytuacją komunikacji językowej, np.: głosić - por. Mt 9, 35 (BT), nauczać - por. Łk 8, 1 (BT), nieść - por. 2 Kor 10, 16 (BT), opowiadać - por. Łk 4, 18 (BW), powiadać - por. Łk 4, 18 (BN), stuchać - por. Kol 1, 5 (BT) oraz zwroty: dać postuch, dać świadectwo, dopetnić obwieszczenia itp., a także z odpowiedzią człowieka na głoszenie Ewangelii: wierzyć, nawracać się, a nawet stracić życie.

Przedmiotem gloszenia jest zatem Ewangelia. Jaka Ewangelia? Ewangelia o królestwiel Ewangelia królestwal Ewangelia o królestwie Bożym/ Ewangelia o Jezusie Chrystusiel Ewangelia Chrystusal Ewangelia Bożal Ewangelia łaski Bożej itp. Podmiotem nauczania Ewangelii jest wszelkie stworzenie, wszystkie narody, zwłaszcza zaś poganie i ubodzy. Miejscem głoszenia jest cały świat. Proklamowaniu słowa Bożego towarzyszą w odniesieniu do adresata, miejsca, a także czasu (zawsze) kwantyfikatory uogólniające.

Jakie znaczenie ewangelizacji można z kolei odczytać w KKK? Występuje tu niewielka liczba poświadczeń (zaledwie sześć kontekstów).

Przedmiotem ewangelizacji jest Dobra Nowina Wcielenia $i$ Zmartwychwstania Chrystusa (p. 333), Chrystus (p. 905). Do głoszenia Ewangelii wezwani są wszyscy uczniowie Chrystusa (p. 1533) ze wskazaniem - poza stanem duchownym - świeckich (p. 906), w tym rodzin chrześcijańskich (p. 2205). Ewangelizacji podlega świat, głosi się zatem ją w zwyktych warunkach właściwych światu (p. 905). Jej dzialaniami sprawczymi są: wypetnienie misji prorockiej [Chrystusa] 
(p. 905) oraz wplyw na owoce liturgii: nowe życie wedtug Ducha, zaangażowanie w postanie Kościoła i stużbę na rzecz jego jedności (p. 1072). U podstaw powołania do ewangelizacji (jej uwarunkowań) leżą sakramenty (p. 1533). Ewangelizacja wymaga też m.in. obecności życia zakonnego w jego różnych formach (p. 927). W koniunkcji z nią występują: wiara, nawrócenie, świętość. Jest ona więc definiowana jako 'głoszenie Chrystusa [...] zarówno świadectwem życia, jak i słowem' (p. 905). W kategorii działania ewangelizacji (co robi ewangelizacja?) można wskazać, iż ewangelizacja nabiera swoistego charakteru i szczególnej skuteczności (p. 905), dokonuje się (p. 905), powinna poprzedzać liturgię (p. 1072), zaś kategorii coś ewangelizacji odpowiadają poczatki ewangelizacji (p. 927), misja ewangelizacji (p. 929).

W nauczaniu katolickich ewangelizatorów i protestanckich charyzmatyków przedmiotem ewangelizacji jest Ewangelia. Jednak protestanccy ewangelizatorzy precyzują jej rozumienie. Głoszą zatem Ewangelię, która jest racjonalna, ale także przerasta naturalność (Wim: 43).

Wszyscy ewangelizatorzy ukonkretniają przedmiot głoszenia. Kapłani i świeccy zgromadzeni na rekolekcjach ewangelizacyjnych (For) wskazują, np.: Chrystusa i Jego ukrzyżowanie (s. 37), Dobra Nowinę, że nasz Pan - Jezus Chrystus ocalił nas poprzez swój krzyż, poprzez Swoja śmierć $i$ wspaniate zmartwychwstanie (s. 37) (tak też Koz: 36). U Johna Wimbera i Kevina Springera są to: Chrystus (s. 43), Ewangelia o Królestwie Bożym (s. 45).

Podmiot, któremu katoliccy księża (For) głoszą Ewangelię to, zgodnie z nakazem Biblii: cały świat (s. 33, s. 37), zwłaszcza zaś biedni i cierpiący (s. 35). Wskazują oni cel misyjny ewangelizacji, a więc, np. docieranie do plemion w regionie saharyjskim w Afryce (s. 37) oraz cele pastoralny bądź powtórnej ewangelizacji, czyli głoszenie skierowane m.in. do: ochrzczonych chrześcijan (s. 37), Kościoła i jego członków (s. 149). Jednak grupę docelową stanowią przede wszystkim: środowisko domowe, domownicy, rodzina (s. 85). U protestanckich ewangelizatorów, a także w nauczaniu o. Antonello Cadeddu i o. Henrique Porcu są to głównie: nieznajomi ludzie (Wim: 124), społeczeństwa zachodnie (Wim: 47), bezdomni (CadPor: 18), nasza młodzież (Wim: 36), młodzi (CadPor: 74), bracia z ulicy (CadPor: 98). J. Wimber wprowadza ponadto rozróżnienie na ewangelizacje programowa, która adresatem czyni wszystkich napotkanych (s. 53) i ewangelizację w mocy, która jest precyzyjnie, dzięki duchowemu rozeznaniu, skierowana do określonej osoby lub grupy ludzi (s. 53), czyli jest celowa. Obejmuje niewierzących, w tym ludność plemienna (s. 28) oraz nominalnych członków Kościołów (s. 117).

Wzorem ewangelizatora jest Jezus. Kto zaś na ziemi jest powołany do ewangelizacji? Według J. Wimbera oraz oo. Cadeddu i Porcu: chrześcijanie (Wim: 53), młodzi (CadPor: 74). Ewangelizator z Ameryki wskazuje ponadto, iż mało skuteczni są: Kościót chrześcijański (s. 44), zachodni chrześcijanie (s. 49), kaznodzieje (s. 52). Katoliccy rekolekcjoniści (For) jako ewangelizatorów wskazują: stan duchowny (np. studzy Pana: biskupi, zakonnicy, księża-s. 38) i świeckich 
(np. zwykli chrześcijanie, „Chrystofideles laici” — s. 38). Wyrażają to expressis verbis: duchowieństwo i laicy pracujacy razem w ewangelizacji (s. 108). Ewangelizują ponadto: Kościół, Msza św., Maryja.

\section{Miejsce ewangelizacji — gdzie?}

J. Wimber podaje szereg odniesień biblijnych, zestawiając je z działaniem ewangelizacji w mocy. Są to: pierwszy Kościót (s. 43), dom strażnika więzienia w Filippi, Kafarnaum (s. 66-67). Ponadto wskazuje obszary, na których są już widoczne efekty działania ewangelizacji w mocy, np. Seattle-Tacoma (s. 46), Anglia (s. 47), cały obszar Morza Śródziemnego (s. 100) i tzw. tereny misyjne, do których trzeba dotrzeć z ewangelizacją: Afryka, Poludniowa i Centralna Ameryka i Azja (s. 52), a także bliżej nieokreślone: okolica (s. 36), kraje nierozwinięte (s. 48).

Katoliccy rekolekcjoniści (For) wskazują miejsca ewangelizacji w zależności od jej rodzaju i charakteru - misyjnego, np. w Azji, w Afryce; pastoralnego, np. wewnatrz Kościoła Katolickiego (s. 104), w nowych kościołach Afryki, Azji i Oceanii (s. 49) czy skierowanego do tzw. nominalnych chrześcijan: $w$ starych kościołach Włoch, Francji, Hiszpanii, i części Ameryki Łacińskiej (s. 49). Mówiąc o miejscu ewangelizacji, przywołują również nakaz biblijny: cały świat (s. 33, s. 37). O. Kozłowski jako środowisko i miejsce ewangelizacji podaje bardzo konkretnie: parafie i rodziny (s. 12). Analogicznie głoszą rekolekcjoniści (For) — przez ,oikos”, stowo greckie, które znaczy ,środowisko domowe, domownicy, rodzina” (s. 85).

Ojcowie Cadeddu i Porcu koncentrują się przede wszystkim na nowej ewangelizacji. Wskazują zatem: ośrodki dla nieletnich (s. 112), miasta: na ulicy w centrum Sao Paulo (s. 136), na ulicach (s. 58), w centrum miasta (s. 207).

\section{Czas ewangelizacji — kiedy?}

J. Wimber, jak już wspomniano, w wielu kontekstach utożsamia ewangelizację w mocy z tą z czasów apostolskich i początków Kościoła. Zatem jej czas obejmuje np.: dziatania misyjne opisane w Nowym Testamencie (s. 47), w pierwszym Kościele (s. 43) itp., a także później — w czasach wielkiej odnowy i ekspansji misyjnej, opisanych w historii Kościoła (s. 43). Powołuje się również na ewangelizacje prowadzone w konkretnych miejscach i czasie.

Z kolei ojcowie rekolekcjoniści (For) odwołują się do biblijnego rozumienia czasu ewangelizacji - „w pore, nie w porę” (2 Tym 4,2), ewangelizować kiedy jest okazja, ale również, kiedy nie jest to bezpieczne lub wygodne (s. 38), dzisiaj (Koz: 75). 


\section{Sposoby i metody ewangelizacji — jak?}

Ewangelizatorzy wiele miejsca poświęcają temu, jak ewangelizować. J. Wimber koncentruje się na znakach i cudach, uznając je za niezbędne do skutecznego ewangelizowania. Głosi zatem: nasza ewangelizacje powinny potwierdzać znaki (s. 92), Wyttumaczenie Ewangelii przychodzi z objawieniem się mocy Bożej przez znaki i cuda (s. 43). Z wysoką frekwencją używa określeń nadprzyrodzony, nadnaturalny - por. ewangelizacja powinna odbywać się w nadprzyrodzony sposób (s. 43); w jej trakcie następuje nadprzyrodzone poznanie czyjegoś grzechu (s. 43), nie przez zwiastowanie, ale przez nadnaturalna obecność (s. 63).

Do konkretnych metod proponowanych przez katolickich księży (For) należą natomiast: dawanie świadectwa (np. s. 29), bycie w Kościele, wiara w Kościół i czynny udział w życiu Kościoła (np. Ponieważ łódź Piotra przedstawia Kościót, przekaz ten jest efektywna ewangelizacja czyniona w Kościele, z Kościotem i poprzez Kościót - s. 110), otwarcie na Ducha św. (np. w tej odmianie ewangelizacji pod przewodnictwem Ducha: przez modlitwę, pokorę, mitość i krzyż - s. 104). Podkreślają oni szczególną rolę sakramentów (np. sakramenty moga być efektywnym środkiem ewangelizacji i reewangelizacji - s. 25-26), sakramentaliów (np. sakramentalia sa doskonatymi środkami do ewangelizacji - s. 30), adoracji Najświętszego Sakramentu (np. Jezus wypetnia nas natchnieniem i zapatem do ewangelizacji - s. 54), a także rolę rekolekcji (s. 102), działania zakonów misyjnych (s. 61). Te same metody są obecne w nauczaniu O. Kozłowskiego (por. s. 5). Jest to zgodne z rozumieniem ewangelizacji w KKK — głoszenie Chrystusa świadectwem życia, w warunkach właściwych światu, a także z nauczaniem Jana Pawła II — por. Potrzebne jest radykalne nawrócenie i bardziej wyraziste świadectwo o Chrystusie, stąd najważniejsza i najskuteczniejsza metoda nowej ewangelizacji jest świadectwo życia wiara osób i wspólnot (List apostolski Jana Pawła II do młodych całego świata, 1985).

Współcześni ewangelizatorzy (CadPor) koncentrują się - analogicznie do ponaddenominacyjnych nauczycieli — na znakach, cudach i walce duchowej, rozumianej jako uwolnienia spod wpływów demonicznych. Są to - według nich — metody konieczne do ewangelizacji — por. Nie możemy już głosić Ewangelii bez proszenia Jezusa o zestanie na ziemie płomienia, który dokonuje uzdrowień i cudów (s. 134) i wiele innych.

\section{Okoliczności zaistnienia (uwarunkowania) ewangelizacji — jakie?}

W nauczaniu Johna Wimbera przygotowanie do ewangelizacji jest ściśle związane z metodami i sposobem ewangelizowania. Niezbędne są zatem: przy- 
gotowanie do wykonywania znaków i cudów (s. 102), namaszczenie przez Ducha Świętego, stużace demonstracji mocy (s. 51).

Podczas rekolekcji ewangelizacyjnych zgromadzeni tam kapłani i świeccy (For) dużo miejsca poświęcili uwarunkowaniom ewangelizacji. Za jeden z najważniejszych warunków uznali świętość (por. nasza świętość jest warunkiem, który Bóg wymaga dla efektywnej ewangelizacji - s. 150) oraz związane z nią nawrócenie (np. jednym z wymagań ewangelizacji, jedna z podstawowych potrzeb, by każda osoba mogła przyjąć Chrystusa - jest nawrócenie lub pokuta - s. 28, por. s. 110-111). Ponadto wskazują: maryjność, jedność Kościoła, poddanie się działaniu Ducha św., życie sakramentalne.

Ojcowie Antonello i Enerique eksponują: cierpienie, świadectwo i modlitwe (por. s. 118-119), jedność i postuszeństwo pasterzom (s. 230-231).

\section{Działania sprawcze ewangelizacji — jaki cel? skutek?}

Katoliccy ewangelizatorzy (For) za cele ewangelizacji i jej działania sprawcze uznają m.in.: stużenie (s. 85), prowadzenie ludzi do wiary (s. 24), wewnętrzna przemiane tych, którzy sa ewangelizowani (s. 49), utrzymanie większości praktykujacych $w$ starych Kościołach lokalnych $i, w$ tym samym czasie zatrzymanie exodusu od Kościoła Katolickiego w nowych Kościołach lokalnych (s. 49). O. Kozłowski koncentruje uwagę na: staniu się uczestnikiem zbawienia przynajmniej niektórych (s. 5) i doprowadzeniu człowieka do osobistego spotkania ze zmartwychwstatym Chrystusem (s. 74). Natomiast oo. Cadeddu i Porcu na przemianie życia ludzi i społeczeństwa (s. 53).

Zakładane cele, zadania i skutki ewangelizacji wyrażone w nauczaniu J. Wimbera to m.in.: nawrócenie (s. 33, 53), powołanie indywidualnych uczniów Jezusa i budowanie grup ludzi, ciała Chrystusowego (s. 66), uczestnictwo w nabożeństwach (s. 44), wzrost zarówno liczebny, jak $i$ w dojrzałości członków zborów (s. 52), działanie w zborach stałej stużby znaków i cudów (por. s. 52). Skuteczność ewangelizacji mierzy się ilościq osób, które w imieniu Pana uzyskały pomoc (s. 54), a także raportami o znakach i cudach oraz wzroście Kościoła (s. 49).

\section{Definicje ewangelizacji}

Cechą definicyjną ewangelizacji jest 'mówienie i/lub robienie czegoś, co ma związek z Ewangelią'.

Ponaddenominacyjni ewangelizatorzy (Wim) definiują ewangelizację jako 'złożony proces, w czasie którego Duch Święty działa w sercach i umysłach ludzi. Podstawą tego procesu jest komunikacja' (s. 59). Jednak przywoływana w defi- 
nicji komunikacja ma dwa poziomy — naturalny i nadnaturalny. Poza terminem ewangelizacja posługują się oni bowiem nominacją ewangelizacja w mocy, używaną z najwyższą frekwencją. Już modyfikacja nazwy, wskazująca cechę ewangelizacji, jaką jest moc, wpływa na zmianę jej znaczenia. Ewangelizacja w mocy w przeważającej liczbie kontekstów jest synonimem ewangelizacji - por. ewangelizacja w mocy jest normalnym typem głoszenia Ewangelii (s. 43-44), w innych zaś jej zasadniczą częścią — por. ewangelizacja w mocy jest katalizatorem, działajacym w obrębie zadań programowych (s. 54). Autorzy rozumieją ją jako: 'prezentowanie Ewangelii, która jest racjonalna, ale także przerasta naturalność' (s. 43), 'biblijne jak i osobiste doświadczenie cudów' (s. 11), 'demonstrację Bożej mocy przez znaki i cuda' (s. 55). Ponadto wskazują, iż jest to: 'proste przedstawienie Ewangelii' (s. 54), 'coś prostego, prawie dziecinnego' (s. 141). Kolejny termin - ewangelizacja programowa - jest definiowany jako 'współczesne wysiłki ewangelizacyjne Zachodu' (s. 52). Wimber posługuje się ponadto nominacjami ewangelizacja pierwszego Kościoła i ewangelizacja przekonania, które utożsamia z ewangelizacja w mocy. Ewangelizacje pierwszego Kościoła definiuje jako 'świadectwo, iż Chrystus jest wypełnieniem proroctw mesjańskich. Potężna prezentacja Królestwa Bożego potwierdziła jego zwiastowanie' (s. 56). Ewangelizacje przekonania nazywa wprost Bożym ideałem i definiuje jako 'najlepszy rodzaj ewangelizacji, ponieważ przeprowadza ludzi z fazy decyzji do fazy uczniostwa' (s. 54). Zakres znaczeniowy pokrywający się z ewangelizacja programowa mają zaś ewangelizacja obecności (lub poza obecność) - 'to świadectwo dobrych uczynków' (s. 54) oraz ewangelizacja zwiastowania - tu do dobrych uczynków dodaje dobre stowo (s. 54).

Katoliccy rekolekcjoniści (For) definiują ewangelizację w następujący sposób: 'głosić Chrystusa i Jego ukrzyżowanie' (s. 37), 'nieść całej ludzkości Dobrą Nowinę, że nasz Pan - Jezus Chrystus ocalił nas poprzez swój krzyż, poprzez Swoją śmierć i wspaniałe zmartwychwstanie' (s. 37), 'szczere głoszenie Chrystusa jako Zbawiciela' (s. 39), 'niesienie Dobrej Nowiny do wszystkich ludzi bez wyjątku' (s. 49 za: Evangelii Nuntiandi p. 18), 'te rekolekcje, ta przemowa, każda pasterska inicjatywa i działanie' (s. 102). Denotują one też cel ewangelizacji: 'prowadzenie ludzi do Boga, do świętości' (s. 33). Wskazują na wagę i skomplikowaną naturę ewangelizacji: 'wielkie przedsięwzięcie' (s. 12), 'główne zadanie Kościoła' (s. 21). Dużą rangę zadaniu, jakim jest ewangelizacja, nadają również oo. Cadeddu i Porcu — por. 'Jest ona kwestią życia i śmierci i wymaga całkowitej gotowości na każde poświęcenie' (s. 182, 184), 'Ewangelizacja to dla nas sprawa najwyższej wagi' (s. 53).

Pośród zdań o budowie definicji występują także takie, w których leksem ewangelizacja nie jest członem definiowanym, ale definiującym. W taki sposób zbudowane są zdania utożsamiające ewangelizację ze świętością. Świętość faktycznie staje się ewangelizacją. Świętość staje się głoszeniem Chrystusa $i$ w rzeczywistości samym darem Chrystusa (For: 151). Dotyczy to także zdań 
utożsamiających przymiot ewangelizacji z osobą Boga: Jezus, a nie teorie o Nim, jest Ewangelia, która się głosi (Koz: 75).

Ewangelizatorzy wskazują różne typy ewangelizacji. Są one wyróżniane ze względu na jej dostosowanie do konkretnego odbiorcy oraz towarzyszące temu metody i sposoby ewangelizowania.

Ojcowie rekolekcjoniści (For) w związku z celem misyjnym wyróżniają: pierwsza ewangelizację - daje ona przebudzenie poczatków wiary i możliwość przyjęcia słowa Bożego (s. 52) oraz związaną z docieraniem do środowisk kiedyś chrześcijańskich: druga ewangelizację (powtórną ewangelizację, reewangelizację), czyli poszukiwanie i zawracanie zagubionych owieczek do stada Chrystusa (s. 52). Ponadto, związaną $\mathrm{z}$ dawaniem świadectwa - bezpośrednia ewangelizację. Posługują się również terminem nowa ewangelizacja. Termin ten został po raz pierwszy użyty przez papieża Jana Pawła II, który podkreślał, iż jest to ta sama ewangelizacja, ale nowe są sytuacje społeczne i kulturowe (Bifet 1992: 11-42; Casiraghi 1992). Do jej immanentnych cech zaliczają zatem: entuzjazm, radość (por. Serce radosne jest również znakomite do ewangelizacji - s. 22), gorliwość (por. Uczniowie musza przejawiać w ewangelizacji ten sam zapat, który Jezus okazywat we własnych poszukiwaniach zaginionej owieczki w domu Izraela - s. 51) oraz szacunek dla innych, dlatego pośród jej metod wymieniają też inkulturację (por. s. 7). Jej konstytutywne cechy wyrażają również nominacje: Ewangelizacja, Nowa w Zapale; Ewangelizacja, Nowa w Metodach; Ewangelizacja Nowa w Środkach Wyrazu itp. Nazwą nowa ewangelizacja posługuje się również o. Kozłowski, który wprost pisze, iż jest ona nowa co do swej żarliwości, nowa, co do swych metod i nowa co do swej ekspresji (s. 75, por. For: 83). Nie zmienia się zatem cech definicyjnych pojęcia ewangelizacja. Konotuje natomiast nowy podmiot, metody i formy głoszenia Ewangelii. Połączenie to charakteryzuje duży stopień utrwalenia. Jest notowane przez współczesne opracowania leksykograficzne.

Frazeologizmem nowa ewangelizacja posługują się również oo. Cadeddu i Porcu, jednak zakres semantyczny pojęcia wyrażanego tym terminem pokrywa się u nich z treścią pojęcia ewangelizacja w mocy (Wim). Warunkiem jej zaistnienia są bowiem znaki - por. nowa ewangelizacja wymaga, by „Pan [...] potwierdzit naukę znakami, które jej towarzyszyty" (s. 47). W ewangelizacji koncentrują się na charyzmatach nadzwyczajnych: uzdrowieniach, proroctwach, spoczynkach w Duchu i uwolnieniach. Zatem modyfikują np. treści zawarte w Dzienniczku s. Faustyny (por. s. 132) czy wypowiedzi głowy Kościoła - por. nowa ewangelizacja, której tak pragnąt Papież Jan Pawet II — „,nowa w zapale, metodzie i środkach wyrazu" - [dodają] wymaga silnego doświadczenia Ducha Świętego oraz Jego charyzmatów" (s. 47). 


\section{Działania ewangelizacji}

\section{Działania wobec ewangelizacji - co się z ewangelizacją robi?}

W nauczaniu J. Wimbera ewangelizację się prowadzi, praktykuje, ewangelizacji się uczy bądź też się ją odkrywa, rozwija. Jednak swoistym novum są czasowniki nazywające uczucia i stany — zatem ewangelizacji się doświadcza (s. 44).

U katolickich ewangelizatorów (For) są to natomiast verba dicendi: dawać świadectwa, mówić; nazwy czynności związane z przygotowaniem do głoszenia: pragnać, zainspirować, zmobilizować, zaczać, nauczyć i z działaniem: angażować się, promować, prowadzić itp.

\section{Działania ewangelizacji — co robi ewangelizacja?}

W opracowaniu Ewangelizacja w mocy Wimber gromadzi nazwy czynności o pozytywnym znaczeniu, np. kwitnie (s. 48), może kwitnać (s. 52), pomaga w osiagnięciu celów (s. 54), ale wobec ,posługiwania z mocą”, albowiem skuteczna ewangelizacja powinna się odbywać w mocy Ducha Świętego (s. 90). Wykazuje tym samym różnicę między taką posługą a ewangelizacją programowa, która: usituje dotrzeć (s. 52), przybiera wiele form (s. 52), opóźnia osiagnięcie celów (s. 54). Jednym z aspektów pojęcia ewangelizacja w mocy jest jednak pominięcie woli podmiotu - adresata ewangelizacji, zatem przebija się [ona] przez opór (pochodzacy z niewiedzy albo negatywnego nastawienia), przemieszcza ludzi (usuwając szczególnie negatywne postawy wobec chrześcijaństwa) (s. 62).

Według katolickich ewangelizatorów zgromadzonych na rekolekcjach kapłańskich (For) ewangelizacja może wstrzasnać światem (s. 99), może odwrócić te trendy [chodzi o wzrost ludzi niewierzących] (s. 49), musi dotrzeć do nich i przywrócić im petne uczestnictwo w Kościele (s. 52) itp. Działanie ewangelizacji wiąże się tu bezpośrednio z jej zasadniczymi celami.

\section{Cechy ewangelizacji - jaka?}

Ten aspekt struktury semantycznej ma wiele poświadczeń w analizowanych tekstach. W opracowaniu J. Wimbera dodatnio waloryzowana jest ewangelizacja $w$ mocy. Służy temu użycie określeń o najwyższym stopniu intensywności cechy: petna mocy (s. 43), Boży ideat (s. 54). Ponadto wymienia się jej liczne zalety: spontaniczna, inspirowana przez Ducha Świętego (s. 43), skuteczna (s. 56), efektywna (s. 46), nie jest wykluczona z żadnej kultury (s. 52), nie jest antyracjonalna (s. 62, dotyczy to jednak tylko podstaw Ewangelii). Taka jest też ewangelizacja 
pierwszego Kościoła. Na przeciwległym biegunie stoi ewangelizacja programowa (praktykowana na Zachodzie), która jest: niepetna (s. 54), nie ma takiej mocy (s. 47), bez pomocy darów charyzmatycznych (s. 52). Charakteryzuje się ona zwykle podkreśleniem roli kaznodziejów, przedstawiajacych Ewangelię za pomoca argumentów racjonalnych (s. 52).

Kapłańskie rekolekcje odbywały się „w oczekiwaniu na rok 2000”, dlatego katoliccy rekolekcjoniści (For) używają nominacji: Ewangelizacja 2000; Nowa Ewangelizacja, w oczekiwaniu na rok 2000; Nasza ogólnoświatowa ewangelizacja $w$ przygotowaniu na rok 2000. Ponadto wskazują cechy ewangelizacji - jest ona: prawdziwa (s. 39), nieustanna (s. 97), prorocza (s. 99), misyjna (s. 149), ogólnoświatowa (s. 99), światowa (s. 109), katolicka (s. 104), efektywna (s. 110), petna sukcesu (s. 110).

Dla oo. Cadeddu i Porcu są to m.in.: jednoczesna kerygmatyczna i charyzmatyczna ewangelizacja (s. 48), skuteczna (s. 53), wielka (s. 207), nocna (s. 208).

\section{Części, z jakich składa się ewangelizacja}

\section{Zjawiska związane z ewangelizacją - coś ewangelizacji}

W nauczaniu J. Wimbera to, co przynależy ewangelizacji, jest związane przede wszystkim z jej efektywnością i skutecznością, a więc stosowanymi metodami, a także z jej celem i zadaniem. Są to więc m.in.: podstawy ewangelizacji w mocy (s. 11), efektywne środki ewangelizacji (s. 43), metody ewangelizacji (s. 45), skuteczność ewangelizacji (s. 46), praktyka ewangelizacji w mocy (s. 49), najlepszy rodzaj ewangelizacji (s. 54), katalizator ewangelizacji (s. 109), zwiększone żniwo ewangelizacji (s. 136).

Rekolekcjoniści (For) poza takimi częściami ewangelizacji, jak zadanie, cel, metoda, istota, oddziaływanie, wskazują na trud głoszenia i misyjność głoszenia (np. s. 9: wielka misja Nowej Ewangelizacji, s. 24: dzieło ewangelizacji, s. 28: wymaganie ewangelizacji), poruszają problemy, którymi żyje Kościół (np. s. 102: prawdziwe ekumeniczne zrozumienie ewangelizacji, s. 110: sytuacja ewangelizacji w dzisiejszym Kościele), dawanie świadectwa (np. s. 24: świadectwo Ewangelizacji), podają cechy ewangelizacji (np. s. 11: żywotność $i$ świt Nowej Ewangelizacji, s. 108: fascynujący świat ewangelizacji), w tym jej aktualność (np. s. 153: , kairos” ewangelizacji). W nauczaniu o. Kozłowskiego jest obecne dzieło nowej ewangelizacji (s. 5). Natomiast u oo. Cadeddu i Porcu: czas ewangelizacji (s. 18), ale też ogień ewangelizacji (s. 38) czy w odniesieniu do nowych wspólnot chrześcijańskich w Brazylii — spichlerz nowej ewangelizacji (s. 94). 


\section{To, co służy ewangelizacji — coś do ewangelizacji?}

W nauczaniu oo. Cadeddu i Porcu ewangelizacji służą: dom formacyjny, centrum ewangelizacji (s. 64) i szkoła ewangelizacji (s. 74).

Wprowadzenie do systemu leksykalnego języka polskiego wyrazów ewangelizować (czasy reformacji) i ewangelizacja (doba nowopolska), związane z powiększeniem jego zasobów, nastąpiło najpierw przez neosemantyzację, tj. nadanie nowego znaczenia ewangelii, a następnie utworzenie derywatów słowotwórczych - ewangelizować i ewangelizacja. Wyraz ewangelizacja jest derywatem utworzonym od czasownika ewangelizować za pomocą formantu -acja. Należy do kategorii słowotwórczej nazw czynności o wartości kategorialnej: 'wykonywanie czynności'. Ta kategoria słowotwórcza zaliczana jest do kategorii transpozycyjnych, tj. derywaty mają dokładnie takie samo znaczenie jak ich podstawy słowotwórcze.

Czasownik ewangelizować oznacza 'czynność (mówienie lub działanie) związaną z Ewangelią'. Jest monowalentny — wymaga podmiotu w mianowniku (Nnom - Vf). Walencja fakultatywna jest wyrażona przez dopełnienie w formie biernika. Do istotnych — obligatoryjnych i fakultatywnych — aktantów należą zatem subiekt, obiekt i adresat. Za najistotniejsze cechy semantyczne pojęcia ewangelizacja, którą możemy określić jako 'czynność związaną z Ewangelią', uznano zatem jej przedmiot i podmiot.

Przedmiotem ewangelizacji w KKK oraz w nauczaniu katolickich ewangelizatorów i protestanckich charyzmatyków jest Ewangelia. Protestanccy ewangelizatorzy wskazują jednak inną jej treść. Jest ona racjonalna, ale także przerasta naturalność.

Podmiotem ewangelizacji — według KKK i katolickich rekolekcjonistów z lat 90. — jest, zgodnie z nakazem Biblii, świat. Ponadto: biedni i cierpiacy (Biblia, For, CadPor). W zależności od celu ewangelizacji są to osoby, które nigdy nie słyszały Ewangelii lub tzw. nominalni chrześcijanie. Jednak grupę docelową stanowią osoby najbliższe - środowisko domowe, rodzina, ale też parafia (KKK, For, Koz). W nauczaniu zarówno J. Wimbera, jak i oo. Cadeddu i Porcu Ewangelię głosi się przede wszystkim nieznajomym.

W KKK jako ewangelizatorów wskazuje się uczniów Chrystusa, w tym $d u$ chownych, świeckich, a szczególnie rodziny chrześcijańskie. Ewangelizatorami według ojców rekolekcjonistów są duchowni i świeccy. Ewangelizują ponadto: Kościół, msza święta, Maryja. W przekazie J. Wimbera oraz oo. Cadeddu i Porcu są to ogólnie chrześcijanie, w tym młodzież.

Czynnościom towarzyszą określone warunki: miejsce, czas, sposób, okoliczności zaistnienia. Ponadto istotne są działania sprawcze tych czynności (cel, skutki), ich cechy, zjawiska z nimi związane. Do ważnych cech narzucających strukturę kognitywną badanemu pojęciu należą sposoby i metody działania. Ze sposobem i metodami ewangelizacji ściśle wiążą się jej uwarunkowania. Pojęcie 
ewangelizacji profilują również jej zadania i cele. Na podstawie analiz przeprowadzonych w obrębie tych kategorii można stwierdzić, że pojęcie ewangelizacji ma różny zakres znaczeniowy w nauczaniu Kościoła katolickiego (KKK, For, Koz) oraz w przekazie zielonoświątkowych i współczesnych charyzmatycznych ewangelizatorów. Wskazują na to również jej cechy definicyjne (zarówno w pozycji genus proximum, jak i differentia specifica).

Ponaddenominacyjni ewangelizatorzy definiują ewangelizację jako 'złożony proces, w czasie którego Duch Święty działa w sercach i umysłach ludzi. Podstawą tego procesu jest komunikacja'. J. Wimber z jednej strony wskazuje na komunikację, $\mathrm{z}$ drugiej zaś w miejsce verba dicendi wprowadza czasowniki nazywające uczucia i stany emocjonalne. Koncentruje się zatem nie na czynnościach związanych z mówieniem czy nauczaniem, czyli sferą intelektualną, ale emocjonalną.

Ojcowie Cadeddu i Porcu posługują się tylko terminem nowa ewangelizacja, jednak zakres wyrażanego przezeń pojęcia pokrywa się z treścią wimberowskiej ewangelizacji w mocy, dlatego jest ona jednoczesna kerygmatyczna i charyzmatyczna (s. 48).

Katoliccy rekolekcjoniści (For) definiują ewangelizację m.in. w następujący sposób: 'głosić Chrystusa i Jego ukrzyżowanie'; 'szczere głoszenie Chrystusa jako Zbawiciela' itp. Jest to definicja tożsama z tą z kart Biblii i KKK. Przedmiotowi ewangelizacji, czyli Ewangelii, towarzyszą zatem czasowniki mówienia.

Ma to wpływ na zakres treściowy pojęcia ewangelizacja wyznaczony przez predykator ewangelizować - por. 'nauczać Ewangelii/głosić Ewangelię', a 'doświadczać Ewangelii/przeżywać Ewangelię’2.

Przy poszczególnych kategoriach można wskazać również ekwiwalencje kulturowe, wewnątrz- i międzytekstowe przedmiotu hasłowego. Należy do nich, np. u ponaddenominacyjnych ewangelizatorów oraz u oo. Cadeddu i Porcu, walka duchowa, rozumiana jako uwalnianie spod wpływów demonicznych i towarzysząca jej terminologia militarna ${ }^{3}$.

W ciągu ostatnich 20 lat zauważalna jest w nauczaniu ewangelizatorów Kościoła katolickiego zmiana zakresu semantycznego pojęcia ewangelizacja w kierunku wyraźnej dominacji tego, co ponadnaturalne i emocjonalne. Taki przekaz trafia do określonych odbiorców. Wpisuje się we wrażliwość mirakularną i współtworzy silnie rozwijającą się religijność mirakularną. Może się to wiązać z diagnozowaną przez Benedykta XVI hermeneutyką nieciągłości i zerwania

${ }^{2}$ Z dokonanego przez V. Maldjievą w artykule Duchowość współczesnego człowieka. Analiza danych językowych, porównania zakresów treści pojęcia 'duchowość' również wynika, że najszerszą dystrybucję ma doświadczenie/przeżywanie (w tym: uczucie i jego przejawy, odruch). Ponadto rozumienie duchowości jest zbieżne u chrześcijan i niechrześcijan, a odległe chociażby od ujęcia tomistycznego, czyli ,życia zgodnie z Duchem Świętym” (Maldjieva 2018: 5-18).

${ }^{3}$ Nominacja walka duchowa występuje w KKK tylko 4 razy, a zakresy, które można przyporządkować pojęciu wyrażanemu przez ten termin, to: przezwyciężanie własnych słabości prowadzących do grzechu (implikacja napięcia między dążeniami „ducha” i „ciała”), dążenie do świętości, modlitwa. 
z przeszłością (por. Kobyliński 2016: 249-250), której jedną z konsekwencji jest uzielonoświątkowienie (pentekostalizacja) Kościoła katolickiego, także na poziomie doktryny ${ }^{4}$.

\section{Słowniki}

Podręczny stownik hebrajsko-polski i aramejsko-polski Starego Testamentu, 2000, red. ks. P. Briks, Warszawa.

Słownik języka polskiego S.B. Lindego, 1854-1860 (I-VI), Lwów.

Stownik języka polskiego, 1958-1969 (I-XI), red. W. Doroszewski, Warszawa.

Stownik języka polskiego, 1861 (I-II), Wilno.

Słownik języka polskiego, 1900-1927 (I-VIII), red. J. Karłowicz, A. Kryński, W. Niedźwiedzki, Warszawa.

Słownik polszczyzny XVI wieku, 1996-2014 (I-XXXVI), red. R. Mayenowa, Wrocław-Warszawa-Kraków.

Stownik staropolski, 1953-1993 (I-X) i 1995-2000 (XI), red. S. Urbańczyk, Wrocław-Warszawa-Kraków.

Słownik staropolskiej terminologii chrześcijańskiej, 2001, M. Karpluk, Kraków.

Wielki słownik grecko-polski Nowego Testamentu. Wydanie z petna lokalizacja greckich haset, kluczem polsko-greckim oraz indeksem form czasownikowych, 1994, red. ks. R. Popowski SDB, Warszawa.

\section{Biblie}

BB — Biblia brzeska (1563), 2003, Clifton-Kraków.

BN — Biblia nieświeska (1572), Nieśwież: starodruk ze zbiorów Biblioteki Uniwersytetu Warszawskiego.

BW — Biblia w przekładzie ks. Jakuba Wujka (1599), 2000, transkrypcja typu B tekstu oryginalnego z XVI w., Warszawa.

BG - Biblia gdańska (1632), 1996, Nowy Testament, Kraków; Stary Testament, 2004, Kraków.

BT - Biblia Tysiaclecia, 1980, Poznań-Warszawa.

Biblia Poznańska, 2004.

\section{Teksty}

Cadeddu o. Antonello, Porcu o. Henrique (2015), Boże marzenie, Kraków (skrót: CadPor).

Forrest T. (1997) Rybacy ludzi. Kapłani i świeccy w Nowej Ewangelizacji, Gdańsk-Toruń (skrót: For).

${ }^{4}$ Pentekostalizacja — ogólnoświatowy proces powstawania nowych wspólnot zielonoświątkowych oraz przekształcania wielu innych chrześcijańskich kościołów i związków wyznaniowych w jedną uniwersalną odmianę chrześcijaństwa charyzmatycznego w wymiarze globalnym (por. Kobyliński 2014: 93-130; 2016: 251). 
Kozłowski J. (1997, 2015), Nawrócić się, aby żyć, Łódź (skrót: Koz).

Wimber J., Springer K. (1985, 1991), Ewangelizacja w mocy, Warszawa (skrót: Wim).

\section{Bibliografia}

Apresjan J.D. (1980), Semantyka leksykalna. Synonimiczne środki języka, Wrocław.

Bartmiński J. (red.) (2009), Językowe podstawy obrazu świata, Lublin.

Bartmiński J. (1996), O „Słowniku stereotypów i symboli ludowych” // Stownik stereotypów i symboli ludowych, t. 1, cz. 1, Lublin, http://www.rastko.rs/projekti/etnoling/delo/12018 (dostęp: 18.08.2017).

Bartmiński J., Niebrzegowska S. (1998), Profile a podmiotowa interpretacja świata, [w:] Profilowanie w języku i w tekście, red. R. Bartmiński, R. Tokarski, Lublin, s. 211-224.

Białkowski M. (red.) (2014), Studia Soborowe. Historia i recepcja Vaticanum II, Toruń.

Bifet J.E. (1992), Teologia della evangelizzazione. Spiritualità missionaria, Roma.

Casiraghi G. (1992), La missione nuova frontiera della Chiesa. Un'enciclica missionaria per il duemila, Torino.

Fillmore Ch.J. (1968), The Case for Case, [w:] Universals in Linguistic Theory, red. E. Bach, R.T. Harms, New York, s. 1-88.

Karolak S. (1984), Składnia wyrażeń predykatywnych, [w:] Gramatyka wspótczesnego języka polskiego, red. Z. Topolińska, Warszawa, s. 11-210.

Kobyliński A. (2014), Etyczne aspekty współczesnej pentekostalizacji chrześcijaństwa, „Studia Philosophiae Christianae" 50, nr 3, s. 93-130.

Kobyliński A. (2016), Hermeneutyka nieciagłości i pentekostalizacja. Współczesne metamorfozy religii chrześcijańskiej, „Teologia i Moralność” 20, nr 2, s. 245-261.

Kulwicka-Kamińska J. (2008), Ewangelia, Pięcioksiag, Psalm, Tora $w$ dawnych i współczesnych translacjach biblijnych i koranicznych, [w:] Tradycja a nowoczesność, red. E. Woźniak, Łódź, s. $101-114$.

Kulwicka-Kamińska J. (2008-2009), Sposoby przekładu chrześcijańskiej i muzułmańskiej terminologii religijnej w polskich translacjach biblijnych i koranicznych, [w:] Chrestomatia teolingwistyki, red. A. Gadomski, C. Lapicz, Symferopol, s. 333-348.

Maldjieva V. (2018), Duchowość według współczesnego człowieka. Analiza danych językowych, „Roczniki Kulturoznawcze KUL” 9, nr 4, s. 5-18.

Mattei R. de (2012), Sobór Watykański II. Historia dotąd nieopowiedziana, przeł. S. Orzeszko IBP, red. T. Mazur, A. Meller, Ząbki.

Nikitina S. (1992), Metajazyki opisanija fol'klornojj leksiki i nauchnojj terminologii, [w:] Systematyzacja pojęć w stylistyce, red. S. Gajda, s. 63-68.

Paweł VI, adhortacja apostolska „Evangelii Nuntiandi”, 8 grudnia 1975.

Różyło A., O głównych cechach znaczenia wiary w Katechizmie Kościoła Katolickiego, http://www. pedkat.pl/images/czasopisma/pk5/art17.pdf (dostęp: 14.06.2017).

Rutkowska I. (2015), Pojęcie miłosierdzia w Dzienniczku św. Faustyny Kowalskiej (część I), „Łódzkie Studia Teologiczne" 24, nr 4, s. 71-89.

Szarlej J. (2011), Językowy obraz człowieka w księgach proroków „mniejszych”, „Świat i Słowo”, nr 1 (16), s. 25-40.

Tokarski R. (1988), Konotacja jako składnik treści słowa, [w:] Konotacja, red. J. Bartmiński, Lublin, s. 35-54.

Wierzbicka A. (1985), Lexicography and conceptual analysis, Ann Arbor.

Wiltgen o. R.M. (2001), Ren wpada do Tybru. Historia Soboru Watykańskiego II, Poznań. 


\section{Źródła internetowe}

http://sjp.pl/ewangelizacja (dostęp: 17.07.2017).

https://pl.wiktionary.org/wiki/ewangelizacja (dostęp: 22.07.2017).

Paweł VI, Adhortacja apostolska Evangelii Nuntiandi, https://opoka.org.pl/biblioteka/W/WP/pawel_vi/adhortacje/evangelii_nuntiandi.html (dostęp: 25.07.2017)

\section{In the stream of the new evangelization: An attempt to reconstruct the linguistic image of evangelization in the Bible, Catechism of the Catholic Church and in texts of contemporary evangelists}

\section{Summary}

The article is an attempt to present the linguistic image of the notion of "evangelization", namely its cognitive structure in the Bible, in the Catechism of the Catholic Church, and in selected source texts, thematically related to the so-called new evangelization. It applies the method of description of the major aspects of a notion, which is used in ethnolinguistics. For evangelization, such aspects are: object and subject of evangelization; the place and time of evangelization; the ways and methods of evangelization; the circumstances related to the event of evangelization (conditions); the effective works of evangelization; the definitions of evangelization; the works focused on evangelization; the acts of evangelization; the features of evangelization; the phenomena related to evangelization; and what serves the purpose of evangelization. On the basis of the presented analysis, it is pointed out that during the last 20 years in the teachings of the Catholic Church's evangelists the semantic range of the notion "evangelization" has changed.

Keywords: cognitive semantics, linguistic image of the world, religious language, evangelization, pentecostalization 